\title{
Exclusive Breastfeeding Intention among Pregnant Women
}

\author{
Intensi Pemberian ASI Eksklusif pada Ibu Hamil
}

Tria Astika Endah Permatasari*, Ratu Ayu Dewi Sartika**, Endang Laksminingsih Achadi**, Urip Purwono***, Anies Irawati****, Dwiana Ocviyanti*****, Evi Martha**

\begin{abstract}
*Department of Nutrition, Faculty of Medicine and Health, University of Muhammadiyah Jakarta, Tangerang Selatan, Indonesia, **Faculty of Public Health, Universitas Indonesia, Depok, Indonesia, ***Faculty of Psycologhy, Universitas Padjajaran, Bandung, Indonesia, ****Research and Development Center of Public Health Effort, Ministry of Health, Jakarta, Indonesia, *****Faculty of Medicine, Universitas Indonesia, Jakarta, Indonesia
\end{abstract}

\begin{abstract}
Exclusive breastfeeding intention is a mother's intention to provide her baby only breast milk since the infant was born until at the age of 6 months. Intention in prenatal period is the direct affirmation of exclusive breastfeeding. This study aimed to find out the most dominant factor related to exclusive breastfeeding intention among pregnant women at a mother and child hospital in South Tangerang. A cross-sectional study design was conducted primarily. The samples were 143 pregnant women on their third trimester pregnancy selected by purposive sampling. Intention was measured by the Infant Feeding Intention scale questionnaire. Meanwhile, attitude, subjective norms, and perceived behavioral control were measured by the modified Breastfeeding Attrition Prediction Tool questionnaire. Data were analyzed using the multivariate logistic regression analysis. It was $61.5 \%$ mother had strong exclusive breastfeeding intention. Perceived behavioral control dominantly influenced the exclusive breastfeeding intention ( $p$ value $=0.007$; Odds Ratio $3.030 ; 95 \% \mathrm{Cl}=1.361-6.746$ ). The other factors influencing intention were attitude, exposure to exclusive breastfeeding from social media, health workers' support, previous breastfeeding experience and mothers' occupation. A mother with high perceived behavioral control has three times more likely to have 'high exclusive breastfeeding intention' than those having the low ones.
\end{abstract}

Keywords: Exclusive breastfeeding, perceived behavioral control, pregnant women

\begin{abstract}
Abstrak
Intensi pemberian ASI eksklusif adalah intensi ibu untuk memberikan hanya ASI pada bayinya sejak dilahirkan hingga berusia enam bulan. Intensi pada periode prenatal merupakan penentu langsung pemberian ASI eksklusif. Penelitian ini bertujuan mengetahui faktor paling dominan berhubungan dengan intensi pemberian ASI eksklusif pada ibu hamil di sebuah rumah sakit ibu dan anak di Kota Tangerang Selatan. Penelitian dengan desain studi potong lintang dilakukan secara primer. Sampel berjumlah 143 ibu hamil trimester ketiga dipilih secara purposive sampling. Intensi pemberian ASI eksklusif diukur menggunakan kuesioner the Infant Feeding Intentions scale. Sedangkan sikap, norma subjektif dan persepsi kontrol perilaku dinilai menggunakan modifikasi kuesioner Breastfeeding Attrition Prediction Tool. Data dianalisis menggunakan analisis regresi logistik ganda. Sebanyak 61,5\% ibu memiliki intensi kuat memberikan ASI eksklusif. Persepsi kontrol perilaku paling dominan berhubungan dengan intensi pemberian ASI eksklusif, ( $p=0,007$; Odds Ratio 3,030; 95\% Cl $1,361-6,746)$. Faktor lainnya yang berhubungan dengan intensi adalah sikap, keterpaparan ibu terhadap ASI eksklusif dari media sosial, dukungan tenaga kesehatan, pengalaman menyusui sebelumnya, dan pekerjaan ibu dengan persepsi kontrol perilaku tinggi berpeluang tiga kali lebih besar memiliki 'intensi tinggi' untuk memberikan ASI eksklusif dibandingkan ibu berpersepsi kontrol perilaku rendah.

Kata kunci: ASI eksklusif, persepsi kontrol perilaku, ibu hamil

How to Cite: Permatasari TAE, Sartika RAD, Achadi EL, Purwono U, Irawati A, Ocviyanti $D$, Martha E. Exclusive breastfeeding intention among pregnant women. Kesmas: National Public Health Journal. 2018; 12 (3): 134-141. (doi: 10.21109/kesmas.v12i3.1446)

Correspondence: Tria Astika Endah Permatasari, Faculty of Medicine and Health University of Muhammadiyah Jakarta, KH Ahmad Dahlan Street, Ciputat, Tangerang Selatan, Phone: +6221-7492135, E-mail: astika.tria@gmail.com Received: February $19^{\text {th }} 2017$

Revised: June $20^{\text {th }} 2017$

Accepted: July $10^{\text {th }} 2017$
\end{abstract}




\section{Introduction}

Breastfeeding is a natural process. The effectiveness of exclusive breastfeeding since the infant was born until the age of 6 months has direct influence with intention. Meanwhile, the exclusive breastfeeding intention can be predicted through the attitude, subjective norms and perceived control behavior according to the Theory of Planned Behavior. ${ }^{1}$ The high intention or mother's will to provide exclusive breastfeeding in prenatal period is proven to contribute to significant effect on the effectiveness of exclusive breastfeeding. ${ }^{1-3}$

World Health Organization (WHO) recommends exclusive breastfeeding for optimum growth, development and infant's health. It is supported by the increase of scientific study about the benefit of exclusive breastfeeding. ${ }^{4-6}$ Skin-to-skin contact during breastfeeding also has a role on the development of infant's Intelligence Quotient and Emotional Intelligence. ${ }^{7}$ Even though exclusive breastfeeding becomes a global health recommendation, but it only covers around $40 \%$ in the world. ${ }^{8}$ In 2014, Center of Disease Control and Prevention reported that $80 \%$ of infants born in the United States did not get exclusive breastfeeding. ${ }^{9}$ Longitudinal study in 2015 in Jiangyou, China also showed that 39\% of 695 mothers stopped breastfeeding their infants before the age of 6 months. ${ }^{10}$

The exclusive breastfeeding coverage was increasing in several countries, but it decreased in other countries. In Indonesia, based on Indonesia Health Profile Data, the provincial coverage for exclusive breastfeeding decreased from $54.3 \%$ to $52.3 \%$ in $2013-2014$, and increased to $55.7 \%$ in 2015.11 One of the provinces with exclusive breastfeeding exceeding the national coverage is Banten Province $(65.8 \%)$, however, its coverage is lower than Special Capital Region of Jakarta at $67.1 \%$. In general, the coverage of exclusive breastfeeding in Indonesia is still lower than the national target $(80 \%) .{ }^{11}$

The coverage of exclusive breastfeeding remains low in several areas. Rosha and Utami, ${ }^{12}$ reported that $44 \%$ of mothers in Bogor, West Java in 2013 provided pralacteal foods to infants when breastmilk did not come out and failed to provide exclusive breastfeeding. A similar study in Subang showed that as much as $38.6 \%$ of mothers providing exclusive breastfeeding. ${ }^{13}$ Amran and Amran, ${ }^{14}$ in 2012 also reported that of 401 mothers in South Tangerang City, there were $43.6 \%$ of mothers providing exclusive breastfeeding.

Based on Health Profile of Banten Province, the coverage of exclusive breastfeeding in South Tangerang City increased from $16.1 \%$ in 2011 to $49.2 \%$ in 2012.15 However, its coverage is fluctuating because South Tangerang City is an urban and industrial area where most of the population are migrants and employed.
Mothers generally have antenatal care in health facilities, especially in a mother and child hospital. ${ }^{15}$

The low coverage of exclusive breastfeeding is directly affected by the weak mother's intention to provide exclusive breastfeeding since the pregnancy period. ${ }^{16-17}$ Intention is influenced by attitude, subjective norms and perceived behavioral control and controlled by covariate variables, such as education, occupation, parity, previous mother's breastfeeding experience, social support, and exclusive breastfeeding exposure from social media. ${ }^{3,18}$ In Indonesia, the study of exclusive breastfeeding intention still needs to be explored, especially using hospitalbased sampling technique. Previous studies on intention also have not explained the method clearly yet, so it was difficult to be replicated widely. ${ }^{19,20}$ The purpose of this study was to find out the dominant factor related to the exclusive breastfeeding intention among pregnant woman.

\section{Method}

A cross-sectional study design was conducted on the population of pregnant mothers having antenatal care in a mother and child hospital, in South Tangerang City in September-November 2016. Based on Hypothesis Test for a Population Proportion with two-sided test approach, a minimum sample of 130 pregnant women on their third trimester pregnancy, which is calculated based on the population proportion of the previous study, was required by purposive sampling technique. An additional of $10 \%$ sample was added to anticipate drop-out. The total sample of 143 pregnant women was then selected for this study.

Women included in the study were those who regularly attended antenatal care (at least twice); those who were in their last trimester of pregnancy, when the intention had already strongly formed; those who were at least 18 years of age who were physically and mentally ready for pregnancy. ${ }^{18}$ Those willing to participate filled out the questionnaire and agreed to sign informed consent. Mothers who were free of any serious health conditions during pregnancy that can complicate the breastfeeding process were excluded.

Intention as dependent variable was measured by adapting original questionnaire of the Infant Feeding Intention (IFI) scale which was first developed by Nommsen-Rivers in prenatal clinic of University of California. ${ }^{21}$ It had been valid and reliable in different culture adaptation. ${ }^{22}$ The IFI questionnaire was adapted (questionnaire use permit, forward and back translation process, panel of lactation expert, panelist readability, and validity and reliability test. It was used after proven valid dan reliable (corrected item-total correlation was between 0.328-0.398 and Cronbach Alpha $0.713)$. 
The IFI questionnaire consisted of five items about mother's plan that were to give her infant only formula milk feed her baby; to breastfeed her baby; to breastfeed without using any formula/other milk when the infant is one month old; to breastfeed without using any formula/other milk when baby is three months old, and to breastfeed without using any formula/other milk when baby is six-months-old. This questionnaire assessed on five points Likert scale (anchor:'very much agree' to 'very much disagree'). This assessment applied inversely to items 2,3,4 and 5. Total intention score was calculated using formula: addition of (mean score of item 1+2) + (total score of item 3,4, and 5). Thus the total score had the range of 0 (strong intention to not breastfeeding at all) until 16 (the strong intention to provide breastfeeding as the only source of food for infants in the first 6 months). ${ }^{21}$ The score was categorized based on the mean score that were 'low intention' if the score less than mean, and 'high intention' if the score greater than equal to mean.

The independent variables were attitude, subjective norms and perceived behavioral control as intentionbased predictor. ${ }^{23}$ These three variables were measured by modified Breastfeeding Attrition Prediction Tool (BAPT), which was first developed by Janke, assessed six point Likert scale. ${ }^{24}$ It has been adapted in several countries. $1,3,25$ The modified BAPT consisted of 56 items (30 items of attitude, 16 items subjective norms, and 10 items perceived behavioral control) with internal consistency range from 0.78 to 0.86 .

Attitude to breastfeeding (30 items consisting of 16 postive items and 14 negative items) consist of two factors that were mother's positive or negative judgment of breastfeeding, and evaluation of the outcomes of it for them and their infants. For example, the positive question 'Breastmilk is more nutritious than infant formula milk'; negative question 'Breastfeeding is painful').24-25 The mothers were asked to rate on a 6-point Likert scale. All scores were summed and categorized by median, namely 'negative attitude' if the score of attitude was less than median, and 'possitive attitude' if the score greater than equal to median. Subjective norms (16 items) depended on mother's perception of the significant others' judgment of breastfeeding and if they care about their opinions, for example, the question: 'The baby's father thinks I should...' and assessed on another 6-point Likert scale (anchors: important to unimportant). All scores were summed and categorized into 'low subjective norms', if the score was less than mean, and 'high subjective norms' if the score was greater than equal to mean. Perceived behavioral control is women's perception of the degree of ease or difficulty of breastfeeding (10 items). It was built from information, skills, abilities, feelings, dan dependence on others, for example, the question 'I am physical- ly able to breastfeed'. Then it was assessed on a 6-point Likert scale (anchors: strongly agree to strongly disagree). All scores were summed and categorized into 'low perceived behavioral control' if the score was less than median, and 'high perceived behavioral control' if the score was greater or equal than median.

The control variables were age, education, occupation, parity, previous breastfeeding experience, exposure to formula milk advertising, exposure to exclusive breastfeeding from mass media and social media, and social support measured by a structured questionnaire. Exposure to formula milk advertising came from mass media/social media/health workers/family/peer/religious or community leaders/other). ${ }^{17}$ This variable was categorized into 'low exposure' if the mother got exposure to formula milk advertising less than three times per week from one source of information, and high exposure if the mother got exposure to formula milk advertising greater than or equal to less than three times per week at least from one source of information exposure.

Exposure to exclusive breastfeeding from mass media was the exposure to exclusive breastfeeding information print media/the internet/electronic media, etc. This variable was categorized into 'low expossure' if the mother get exposure of exclusive breastfeding less than three times per week from one source of information, and 'high expossure' if the mother got exposure to exclusive breastfeeding greater than or equal than three times per week at least from one source of information exposure. 26 Exposure to exclusive breastfeeding from social media was the exposure of mother to information about exclusive breastfeeding from social media (BBM/facebook /twitter/whatsapp/instagram/others). ${ }^{17}$ This variable was categorized into low exposure if the mother obtained information on exclusive breastfeeding not everyday from one social media source, and high exposure if the mother got information on exclusive breastfeeding every day at least from one social media source.

Family support was all forms of support to provide exclusive breastfeeding from the husband/parents/inlaws/siblings/other family members. ${ }^{17}$ Peer support was all forms of support provided by mother's peer, such as motivation, sharing breastfeeding experience, etc. Health workers' supports was all efforts provided by midwife/nurse/doctor/obstetrician/nutrition educator/ others to support for exclusive breastfeeding such as motivation, counseling, mentoring, home visit, not promoting formula milk, etc. The calculation of each variable (family/peer/health workers) was similar, in which each variable was summed and categorized into 'less supported' if the score less than median, and 'Supported' if the score greater than equal to median. ${ }^{26}$ Data was analyzed using multivariate logistic regression 
analysis.

This study has passed the ethical clearance test based on the letter of notification of Research Ethics, Faculty of Public Health, Universitas Indonesia (188/UN2.F10/ PPM.00.02/2016). Data collection was conducted primarily by the researcher and assisted by three enumerators (graduates of Publich Health Nutrition). Mothers filled the questionnaire by themselves after getting information about the research and signed the informed consent.

\section{Results}

Table 1 shows that mothers with 'high intention' to breastfeed since the third trimester pregnancy were $61.5 \%$ (mean score of intention in this study was $11.0 \pm 2.5 \mathrm{SD})$. From this figure $(61.5 \%)$, as much as $6.7 \%$ intended to provide exclusive breastfeeding until their infants aged 1 month, 19.5\% mothers intended to breastfeed exclusively until their infants were at the age of 2 months, and $73.8 \%$ intended to provide exclusive breastfeeding (until the age of 6 months).

Mothers with 'positive attitude toward exclusive breastfeeding' were 59.4\% (Table 1). From this figure, most mothers agreed that 'breast milk is more nutritious than infant formula milk' and 'breastfeeding makes mother closer to her infant', while the mothers with 'negative attitudes toward breasfeeding' was $40.6 \%$. Mothers agreed that 'breastfeeding is painful' and 'breastfeeding is more time consuming than formula milk feeding'.

The mothers with 'high subjective norms' were $50.3 \%$. Mothers judged their social environment want them to breastfeed. Most mothers answered that their family wanted them to breastfeed mostly. Mothers with 'high perceived behavioral' were $54.5 \%$. From this figure, mothers with 'high perceived behavioral' control agreed that they 'physically able to breastfeed' $(85.9 \%)$. of 65 mothers $(45.5 \%)$ who had 'low perceived behavioral control', as much as $78.4 \%$ mothers argued that they will not have sufficient milk for their infants.

Mothers aged would older than 30 years were $60.8 \%$, then $78.3 \%$ high educated, $58.0 \%$ employed, $41.3 \%$ primiparous and $43.4 \%$ did not have previous breastfeeding experience. Mothers who got exposure to formula milk advertising during pregnancy were $46.2 \%$, then $70.6 \%$ got exposure to exclusive breastfeeding information from mass media, and $72.7 \%$ got information from social media. Mothers who got support from their

Table 1. Bivariate Analysis

\begin{tabular}{|c|c|c|c|c|}
\hline Variable & Category & Frequency & $\%$ & p Value \\
\hline \multirow[t]{2}{*}{ Exclusive breastfeeding intention } & Low & 55 & 38.5 & \\
\hline & High & 88 & 61.5 & \\
\hline \multirow[t]{2}{*}{ Attitude } & Negative & 58 & 40.6 & 0.050 \\
\hline & Positive & 85 & 59.4 & \\
\hline \multirow[t]{2}{*}{ Subjective norms } & Low & 71 & 49.7 & $0.150 *$ \\
\hline & High & 72 & 50.3 & \\
\hline \multirow[t]{2}{*}{ Perceived behavioral control } & Low & 65 & 45.5 & $0.002^{*}$ \\
\hline & High & 78 & 54.5 & \\
\hline \multirow[t]{2}{*}{ Age } & $<30$ years old & 87 & 60.8 & 0.850 \\
\hline & $\geq 30$ years old & 56 & 39.2 & \\
\hline \multirow[t]{2}{*}{ Education } & Non Higher Education & 31 & 21.7 & 0.700 \\
\hline & Higher Education & 112 & 78.3 & \\
\hline \multirow[t]{2}{*}{ Occupation } & Employed & 83 & 58.0 & $0.050 *$ \\
\hline & Unemployed & 60 & 42.0 & \\
\hline \multirow[t]{2}{*}{ Parity } & Primipara & 59 & 41.3 & 0.348 \\
\hline & Multipara & 84 & 58.7 & \\
\hline \multirow[t]{2}{*}{ Previous breastfeeding experience } & No & 62 & 43.4 & $0.013 *$ \\
\hline & Yes & 81 & 56.6 & \\
\hline \multirow[t]{2}{*}{ Exposure to formula advertising } & Less exposure & 77 & 53.8 & 0.367 \\
\hline & High exposure & 66 & 46.2 & \\
\hline \multirow[t]{2}{*}{ Exposure to exclusive breastfeeding from mass media } & Less exposure & 42 & 29.4 & 0.954 \\
\hline & High exposure & 101 & 70.6 & \\
\hline \multirow[t]{2}{*}{ Exposure to Exclusive breastfeeding from social media } & Less exposure & 39 & 27.3 & $0.123 *$ \\
\hline & High exposure & 104 & 72.7 & \\
\hline \multirow[t]{2}{*}{ Family support } & Less Supported & 25 & 17.5 & $0.047^{*}$ \\
\hline & Supported & 118 & 82.5 & \\
\hline \multirow[t]{2}{*}{ Peer support } & Less Supported & 43 & 30.1 & $0.178^{*}$ \\
\hline & Supported & 100 & 69.9 & \\
\hline \multirow[t]{2}{*}{ Health workers' support } & Less Supported & 54 & 37.8 & $0.050 *$ \\
\hline & Supported & 89 & 62.2 & \\
\hline
\end{tabular}

Notes:

*eligible for multivariate analysis 
Table 2. Multiple Regression Logistic

\begin{tabular}{lllr}
\hline Variabel & p Value & OR & 95\% CI \\
\hline Perceived behavioral control & 0.007 & 3.030 & $1.361-6.746$ \\
Exposure to exclusive breastfeeding form social media & 0.030 & 2.702 & $1.102-6.625$ \\
Attitude & 0.031 & 2.585 & $1.093-6.112$ \\
Health workers' support & 0.029 & 2.472 & $1.095-5.583$ \\
Previous breastfeeding experience & 0.040 & 2.342 & $1.039-5.280$ \\
Occupation & 0.030 & 2.495 & $1.091-5.707$ \\
\hline Constants & $\mathbf{0 . 0 0 0}$ & $\mathbf{0 . 0 0 0}$ & \\
\hline
\end{tabular}

Notes:

OR $=$ Odds Ratio, $\mathrm{CI}=$ Confidence Interval

family for providing exclusive breastfeed were $82.5 \%$, while $69.9 \%$ got from their peer, and $62.2 \%$ got from health workers (Table 1).

Table 1 presents that attitude, subjective norms, perceived behavioral control, occupation, parity, exposure to exclusive breastfeeeding from social media, social support (family, peer and health workers) passed in candidate selection for multivariate analysis ( $p$ value $<0.25$ ) Perceived behavioral control was the most dominant variable related to exclusive breastfeeding intention $(\mathrm{p}$ value $=0.007$; odds ratio $=3.030 ; 95 \% \mathrm{CI}=1,361$ 6,746). A mother with 'high perceived control behavior' had three times more likely to have high exclusive breastfeeding intention than those having the low ones (Tabel 2).

\section{Discussion}

Exclusive breastfeeding intention is defined as mother's will in breastfeeding exclusively until the age of 6 months. ${ }^{25-27}$ In this study, as much as $61.5 \%$ mothers had 'high exclusive breastfeeding intention'. This figure is lower than a previous local study in North Barito, Central Kalimantan, Indonesia that shows 70\% mothers have 'high intention', because mother who attend the pregnant class are those who had good knowledge of breastfeeding generally. ${ }^{19}$ However, in Beirut, Lebanon, there were $87.1 \%$ mothers who had 'high exclusive breastfeeding intention'. Majority of mothers $(62.1 \%)$ are also unemployed, and have higher socioeconomic compared to this study. ${ }^{16}$ The different results are shown by the study in Hong Kong. There were 53.9\% mothers who had 'high exclusive breastfeeding intention'. As much as $26 \%$ of mothers in Hong Kong do not have planning for pregnancy. A mother's decision to breastfeed may be affected if the stress of pregnancy engenders conscious or unconscious negative feelings toward the unborn child. 27

In the study, perceived behavioral control was the most dominant variable related to exclusive breastfeeding intention. Mothers with 'high perceived behavioral con- trol' were three times more likely to have 'high intention' to breastfeed than those having the low ones. Similar to Kafulafula's, ${ }^{1}$ study in Malawi, mothers with had 'high perceived behavioral control' were three times more likely to have high exclusive breastfeeding intention than those with the low intention. ${ }^{1}$ Mothers intend to breastfeed exclusively when they believe they can breastfeed without difficulty, such as physically able to breastfeed, know how to breastfeed, emotionally ready to breastfeed, suggest that breastfeeding is easy, feel confident to breastfeed, believe that they will have sufficient milk for their infants. ${ }^{3,24}$ This study is supported by a previous study in Tegal City, Central Java, Indonesia, which reported that the mother's perception in sufficient milk supply is the main variable which form intention and related to the success of exclusive breastfeeding. ${ }^{28}$

Attitude to breastfeeding was also associated with exclusive breastfeeding intention significantly ( $p$ value < 0.05). Mothers who evaluated exclusive breastfeeding positively had 2.6 times more likely to have 'high exclusive breastfeeding intention' than those with the low intention. Study in Bangladesh in 2011 on 2,400 mothers proved that positive attitude correlated significantly to exclusive breastfeeding intention. ${ }^{29}$ The mothers with had positive attitude to breastfeeding had positive judgment on exclusive breastfeeding and negative judgment about formula milk (for example, the mothers agreed with positive items 'breastfeeding is more convenient than formula feeding', or 'formula milk-fed infants tend to get sick). $3,24,25$

Mothers exposed to exclusive breastfeeding information from social media were 2.7 times more likely to have 'high exclusive breastfeeding intention' than those with the low intention. Of $72.7 \%$ mothers exposed to information from social media, almost $50 \%$ mothers had two or more kinds online social media platforms (most of them use whatsapp and instagram) on their android smartphone. Similar to study by Hauck's, ${ }^{30}$ in 2016, social media socially interactive in the community as well as online has meaningful correlation in increasing intention 
and exclusive breastfeeding practice. Lifestyle changes mothers' social interaction pattern in receiving and actualizing the information to transfer knowledge and information using social media. ${ }^{17}$

In addition, health workers' support was also significantly associated with exclusive breastfeeding intention ( $p$ value $<0.05$ ). The information provided by the health workers were considered credible by mothers. ${ }^{28}$ As much as $50 \%$ mothers said they got support from obstetrician, $35 \%$ from midwives and the rest were from nurses and others health workers. Pregnant mothers gaining support from health workers had 2.5 times more likely to have exclusive breastfeeding intention than those who did not. This result is in line with the previous study which proved that health worker's support significantly related to intention which determined the effectiveness of exclusive breastfeeding. ${ }^{29-30}$

Mother had previous breastfeeding experience in this study tend to have exclusive breastfeeding intention twice higher than those who did not. Similar to study by Mortazavi, et al., 3 mothers who did not have a previous breastfeeding experience admitted that they were lessconfident in exclusive breastfeeding than mothers who had breastfeeding experience. The study also proved that mothers who did not work had 2.5 times more likely to have 'high exclusive breastfeeding intention' than those working mothers. Most of working mothers $(58 \%)$ admitted that they planned to combine breastfeeding with formula milk when they returned to work (after their babies was already aged 2 months). In general, the mothers in this study stated that they worried that they could not express breast milk at work, so that the infant would not obtain sufficient breast milk and nutritional intake unfulfilled. Lau, et al., ${ }^{27}$ in Hong Kong reported that mothers who did not work had 1.07 times more likely to have 'high exclusive breastfeeding intention' than working mothers. Working mothers were at risk to be stressful because of their job and it threatened the exclusive breastfeeding and its continuity. ${ }^{26}$

\section{Conclusion}

More than half of the women in this study have 'high exclusive breastfeeding intention'. It can increase the exclusive breastfeeding coverage if mothers' intention can be applied in real behavior by exclusively breastfeeding the infant until the age of 6 months. The most dominant variable related to exclusive breastfeeding intention is perceived behavioral control. A mother with high perceived behavioral control has three times more likely to have high intention to exclusive breastfeeding than those with the low intention. Attitude to exclusive breastfeeding, exclusive breastfeeding exposure from social media, health worker's support, previous breastfeeding experience, and maternal occupation also associate with exclu- sive breastfeeding intention.

\section{Recommendation}

Exclusive breastfeeding intention should be measured since the first trimester of pregnancy as early detection for the success of exclusive breastfeeding. Therefore, promotive and preventive efforts can be conducted early. Social marketing for exclusive breastfeeding which is conducted mainly by the health workers can be integrated with antenatal care service in the hospital (such as seminar, pregnant mother class, and lactation management training) and through social media. It also needs policies that support working mothers on exclusive breastfeeding. Furthermore, it is necessary to conduct longitudinal to prove that intention is predictor of exclusive breastfeeding by measuring intention since pregnancy until 6 months of exclusive breastfeeding period.

\section{References}

1. Kafulafula UK, Hutchinson MK, Gennaro S, Guttmacher S, Kumitawa A. Exclusive breastfeeding prenatal intentions among HIV-positive mothers in Blantyre, Malawi?: a correlation study. BMC Pregnancy and Childbirth [serial on the Internet]. 2013 [cited 2016 Dec 12]; 13 (203): 1-11. Available from: http://www.biomedcentral.com/14712393/13/203. DOI: 10.1186/1471-2393-13-203

2. Cabieses B, Waiblinger D, Santorelli G, Mceachan RRC. What factors explain pregnant women's feeding intentions in Bradford, England?: A multi-methods, multi-ethnic study. BMC Pregnancy and Childbirth [serial on the internet]. 2014 [cited 2017 Jan 15]; 14(50); 1-13. Available from: http//www.biomedcentral.com/1471-2393/14/50. DOI :10.1186/1471-2393-14-50

3. Mortazavi F, Mousavi SA, Chaman R, Khosravi A, Jill R. Cross cultural adaptation, validity, and reliability of the farsi breastfeeding attrition prediction tools in Iranian pregnant women. Iran Red Crescent Medical Journal [serial on the internet]. March 2015 [cited 2016 Dec 20]; 17(3): 1-9 Available from: https://www.ncbi.nlm.nih.gov/pmc/articles/ PMC4441781/pdf/ircmj-17-03-26354.pdf. DOI: 10.5812/ircmj.26354

4. Zhu B, Zhang J, Qiu L, Binns C, Shao J, Zhao Y. Breastfeeding rates and growth charts - the Zhejiang Infant Feeding Trial. International Journal of Environmental Research and Public Health [serial on the internet]. June 2015 [cited 2017 Jan 1]; 12(7); 7337-47. Available from https://www.ncbi.nlm.nih.gov/pmc/articles/PMC4515659/pdf/ijerph12-07337.pdf.

5. Mwiru RS, Spiegelman D, Duggan C, Liu E, Msamanga G, Aboud S, et al. Relationship of exclusive breast-feeding to infections and growth of Tanzanian children born to HIV-infected women. Public Health Nutrition [serial on the internet]. February 2011 [cited 2017 Jan 5]; 14(7); 1251-8. Available from:https://www.ncbi.nlm.nih.gov/pmc/ articles/PMC3366264/pdf/nihms-334413.pdf. DOI: 10.1017/S136898 001000306X

6. Chris CR, Lars CS, Ludvigsson J, Rosenbauer J, Cinek O, Svensson, J, et al. Breast-feeding and childhood-onset type 1 diabetes: A pooled analysis of individual participant data from 43 observational studies. 
Diabetes Care [serial on the internet]. November 2012 [cited 2016 Dec 17]; 35(11): 2215-25. Available from: https://www.ncbi.nlm. nih.gov/pmc/articles/PMC3476923/pdf/2215.pdf. DOI: 10.2337/ dc12-0438.

7. Rochat TJ, Houle B, Stein A, Coovadia H, Coutsoudis A, Desmond, C, et al. Exclusive breastfeeding and cognition, executive function, and behavioural disorders in primary school-aged children in rural south africa?: A cohort analysis. PLOS Medicine [serial on the internet]. June 2016 [cited 2017 Jan 10]; 13(6): 1-30. Available from: https://www.ncbi.nlm.nih.gov/pmc/articles/PMC4915617/pdf/pmed.1 002044.pdf. DOI:10.1371/journal.pmed.1002044

8. Cai X, Wardlaw T, Brown DW. Global trends in exclusive breastfeeding. International Breastfeeding Journal [serial on the Internet]. 2012 [cited 2016 Dec 10]; 7(12); 1-5. Available from: https://www.ncbi. nlm.nih.gov/pmc/articles/PMC3512504/pdf/1746-4358-7-12.pdf. DOI:10.1186/1746-4358-7-12

9. National Center for Chronic Disease Prevention and Health Promotion [homepage on the internet]. United States: breastfeeding report card; 2014 [updated 2014 July; cited 2016 Dec 10]. Available from: https://www.cdc.gov/breastfeeding/pdf/2014breastfeedingreportcard.pdf

10. Tang L, Lee AH, Binns CW. Predictors of early introduction of complementary feeding?: Longitudinal study. Pediatrics International. 2015. 57: 126-30. DOI: 10.1111/ped.12421

11. Kementerian Kesehatan Republik Indonesia. Profil kesehatan Indonesia tahun 2015 [online]. Jakarta: Kementerian Kesehatan Republik Indonesia; 2016 [cited 2016 Dec 12]. Avaliable from: http://www.depkes.go.id/resources/download/pusdatin/profil-kesehatanindonesia/profil-kesehatan-Indonesia-2015.pdf

12. Rosha BC, Utami NH. Determinants of prelacteal feeding among newborn babies in Kebon Kelapa and Ciwaringin Villages, Bogor. Jurnal Penelitian Gizi dan Makanan [serial on the internet]. June 2013 [cited 2017 Jan 12]; 36(1): 54-61. Available from: http://ejournal.litbang.depkes.go.id/index.php/pgm/article/view/3395/3386.

13. Permatasari TAE, Syafruddin A. Early initiation of breastfeeding related to exclusive breastfeeding and breastfeeding duration in rural and urban areas in Subang, West Java , Indonesia. Journal of Health Research [serial on the internet]. October 2016 [cited 2017 Feb 2]; 30(5): 337-45. Available from: http://www.jhealthres.org/ upload/journal/915/30\%285\%29_tria_p337-345.pdf. DOI: 10.14456/jhr.2016.46

14. Amran Y, Amran VYA. Gambaran pengetahuan ibu tentang menyusui dan dampaknya terhadap pemberian ASI eksklusif. Jurnal Kesehatan Reproduksi [serial on the internet]. April 2012 [cited 2017 Jan 10]; 3(1): 52-61. Available from: http://ejournal.litbang.depkes.go.id/index.php/kespro/article/view/3930/3773

15. Dinas Kesehatan Provinsi Banten. Profil kesehatan Provinsi Banten tahun 2012 [online]. Banten: Dinas Kesehatan Provinsi Banten; 2013. Available from: http://dinkes.bantenprov.go.id/upload/article_doc/ TABEL_PROFIL_PROV_BANTEN_2013.pdf

16. Hamade H, Chaaya M, Saliba M, Chaaban R, Osman H. Determinants of exclusive breastfeeding in an urban population of primiparas in Lebanon?: a cross-sectional study. BMC Public Health [serial on the nternet]. July 2013 [cited 2016 Dec 15]; 13(702): 1-10. Available from: https://www.ncbi.nlm.nih.gov/pmc/articles/ PMC3737045/pdf/14712458-13-702.pdf. DOI: 10.1186/1471-2458-13-702

17. Permatasari TAE, Sartika RAD, Achadi EL, Purwono U, Irawati A, Ocviyanti D, et al. Does breastfeeding intention among pregnant mothers associated with early initiation of breastfeeding?. Jurnal Kesehatan Reproduksi [serial on the internet]. December 2016 [cited 2017 Jan 10]; 7(3): 169-84. Available from: http://ejournal.litbang.depkes. go.id/

18. Babakazo P, Donnen P, Akilimali P, Mapatano N, Ali M, Okitolonda E. Predictors of discontinuing exclusive breastfeeding before six months among mothers in Kinshasa?: a prospective study. International Breastfeeding Journal [serial on the internet]. May 2015 [cited 2017 Jan 11]; 10(19): 1-9. Available from: https://www.ncbi.nlm.nih.gov/pmc/articles/PMC4464639/pdf/13006_2015_Article_44.pdf. DOI 10.1186/s13006-015-0044-7

19. Puspita YA. Perbedaan persepsi kontrol diri ibu hamil terhadap intensi ibu untuk memberikan ASI eksklusif pada kelas ibu hamil plus di Puskesmas Muara Teweh, Kabupaten Barito Utara. Jurnal EduHealth [serial on the internet]. September 2015 [cited 2017 Feb 3]; 5(2): 123 30. Available from: http://www.journal.unipdu.ac.id/index.php/ eduhealth/article/view/479/426.

20. A'yuni F. Pengetahuan tentang menyusui dan intensi menyusui pada ibu hamil usia remaja. skripsi [online]. Depok: Fakultas Kesehatan Masyarakat Universitas Indonesia; 2012. Available from: lib.ui.ac.id\%2Ffile\%3Ffile\%3Ddigital\%2F20311853-S43382-pengetahuan $\% 2520$ tentang.pdf

21. Nommsen-Rivers LA. Dewey KG. Development and validation of the infant feeding intentions scale. Maternal and Child Health Journal. 2008; 13(3): 334-42.

22. Nommsen-rivers LA, Cohen RJ, Chantry CJ, Dewey KG. The infant feeding intentions scale demonstrates construct validity and comparability in quantifying maternal breastfeeding intentions across multiple ethnic groups. Maternal and Child Nutrition. 2010; 6(3): 220-7. DOI: 10.1111/j.1740-8709.2009.00213.x

23. Ajzen I, Cote NG. Attitude and the prediction of behavior. In: Crano WD and Prislin. Attitude and Attitude Change. New York: Psychology Press; 2008. p. 289-311.

24. Janke JR. Development of breastfeeding attrition prediction tool. Nursing Research. 1994; 43(2): 100-104

25. Muslu GK, Basbakkal Z, Janke JR. The turkish version of breastfeeding attrition prediction tool. Journal of Human Lactation [serial on the internet]. September 2011 [cited 2017 Jan 12]; 27(4): 350-7. Available from: http://jhl.sagepub.com/content/early/2011/09/16/08903 34411410692. DOI: 10.1177/0890334411410692

26. Abdullah GI, Ayubi D. Determinan perilaku pemberian air susu ibu eksklusif pada ibu pekerja. Kesmas: National Public Health Journal [serial on the internet]. February 2013. [cited 2016 Dec 18]; 7(7): 298303. Avaliable from: http://journal.fkm.ui.ac.id/kesmas/article/ view/27/28

27. Lau Y. Breastfeeding intention among pregnant hong kong chinese women. Maternal Child Health Journal. 2010; 14: 790-8. DOI: 10.1007/s10995-009-0506-x.

28. Prabasiwi A, Fikawati S, Syafiq A. ASI eksklusif dan persepsi ketidakcukupan ASI. Kesmas: National Public Health Journal [serial on the 
Permatasari et al, Exclusive Breastfeeding Intention among Pregnant Women

internet]. February 2015 [cited 2017 Feb 5]; 9(3): 282-7. Available from: http://journal.fkm.ui.ac.id/kesmas/article/view/691/458.

29. Thomas JS, Yu EA, Tirmizi N, Owais A. Maternal knowledge, attitudes and self-efficacy in relation to intention to exclusively breastfeed among pregnant women in rural Bangladesh. Maternal Child Health Journal. 2015; 19: 49-57. DOI 10.1007/s10995-014-1494-z
30. Hauck YL, Blixt I, Hildingsson I, Gallagher L, Rubertsson C, Thomson B, et al. Australian , Irish and Swedish women's perception of what assisted them to breasfeed for six month_explanatory design using critical incident technique. BMC Public Health. 2016: 16(1067): 1-12. DOI: 101186/s12889-016-3740-3 